\title{
Cytogenetic and molecular studies on two faba bean cultivars revealed their difference in their aluminum tolerance
}

\author{
Ahmed M. HASSANEIN ${ }^{1,2}$, Ahmed H. MOHAMED ${ }^{3}$, Heba Ahmed ABD ALLAH ${ }^{3}$, Hoida ZAKI ${ }^{3}$ \\ Received November 19, 2019; accepted October 26, 2020. \\ Delo je prispelo 19. novembra 2019, sprejeto 26. oktobra 2020.
}

Cytogenetic and molecular studies on two faba bean cultivars revealed their difference in their aluminum tolerance

Abstract: Two cultivars of faba bean (Vicia faba 'Giza 843' and 'Nobaria 3') that differ in aluminum (Al) tolerance were used to study cytogenetic and genomic alterations under the influence of $\mathrm{Al} \mathrm{Cl}_{3}\left(5,15\right.$, and $\left.25 \mathrm{mmol} \mathrm{AlCl}_{3}\right)$ for different periods $(6,12$ and $24 \mathrm{~h})$. Under $\mathrm{Al}$ treatments, mitotic index in both cultivars decreased and total chromosomal abnormalities increased. The frequencies of micronuclei and chromosomal abnormalities (C-anaphase, metaphase-star chromosomes, breaks, sticky and disturbed chromosomes during metaphase or anaphase) in 'Giza 843' were lower than in 'Nabaria 3'. Increase of the registered cytogenetic events under the influence of $\mathrm{Al}$ stress led to increase the detected polymorphism using RAPD and ISSR markers. Application of RAPD primers gave the same value of polymorphism in both faba bean cultivars under Al stress. Polymorphism average of nine ISSR primers of 'Giza 843' (65.36 \%) was lower than that of 'Nobaria 3' $(71.59 \%)$. Molecular markers, cytogenetic characteristics and seedling growth data indicate that Al tolerance of 'Giza 843' was higher than of 'Nobaria 3'. This work shows that cytogenetic and ISSR techniques could be used efficiently to distinguish between the ability of two faba bean cultivars to tolerate toxic effects of $\mathrm{Al}$.

Key words: aluminum tolerance; Vicia faba L.; chromosomal abnormalities; cytogenetics; RAPD, ISSR
Citogenetske in molekularne raziskave dveh sort boba so odkrile njuno različno toleranco na aluminij

Izvleček: Dve sorti boba (Vicia faba 'Giza 843' in 'Nobaria 3'), ki sta se razlikovali v toleranci na aluminij (Al) sta bili uporabljeni v raziskavi citogentskih in genomskih sprememb, ki so jih povzročile različne koncentracije $\mathrm{Al} \mathrm{Cl}_{3}(5,15$, in 25 mmol $\left.\mathrm{AlCl}_{3}\right)$ v različnih časovnih obdobjih $(6,12$ in $24 \mathrm{~h})$. Pri obravnavanjih z Al se je mitotski indeks obeh sort zmanjšal, celokupne kromosomske aberacije pa so se povečale. Pogostost malih jeder (micronuclei) in kromosomskih aberacij (C-anafaze, zvezdasti kromosomi v metafazi, lomi kromosomov, zlepljeni in nenormalni kromosomi v metafazi in anafazi) sta bili pri 'Giza 843' manjši kot pri 'Nabaria 3'. Povečanje ugotovljenih citogenetskih dogodkov zaradi vpliva Al stresa je povečalo ugotovljeni polimorfizem $z$ RAPD in ISSR označevalci. Uporaba RAPD začetnih oligonukleotidov je dala enako vrednost polimorfizma pri obeh sortah izpostavljenih aluminijevemu stresu. Poprečje polimorfizma devetih ISSR začetnih oligonukleotidov je bilo pri'Giza 843' (65,36 \%) manjše kot pri'Nobaria 3' $(71,59 \%)$. Molekulski označevalvi, citogenetske značilnosti in parametri rasti sejank so pokazali, da je tolerance na aluminij pri ‘Giza 843' večja kot pri 'Nobaria 3'. Raziskava kaže, da bi se citogenetske metode in ISSR tehnike lahko učinkovito uporabljale za razlikovanje sposobnosti tolerance različnih sort na toksične učinke $\mathrm{Al}$.

Ključne besede: toleranca na aluminij; Vicia faba L.; kromosomske aberacije; citogenetika; RAPD; ISSR

1 Sohag University, Faculty of Science, Central Laboratory of Genetic Engineering, Sohag, Egypt

2 Corresponding author, e-mail: Hassaneinam2@yahoo.com

3 South Valley University, Faculty of Science, Botany and Microbiology Department, Qena, Egypt 


\section{INTRODUCTION}

Faba bean (Vicia faba L.) is one of the most important legume plants where it is cultivated for humans as well as animals. Faba bean seeds contain high proteins and other important components. It is a diploid species with $2 n=12$. It belongs to Viceae tribe of Papilionoideae subfamily of Fabaceae family. In general, legume plants are used to improve the fertility of soil through nitrogen fixation. Around the world, 37 collections including about 38,360 faba bean germplasm have been conserved; the largest collection belongs to International Center for Agricultural Research in the Dry Areas - ICARDA in Syria (Duc et al., 2010).

Genetic variation in faba bean ranges from 10 to $60 \%$ depending on plant genotype and the environmental conditions (Suso et al., 2006). Faba bean is cultivated under several conditions, but water deficiency, increased soil salinity and pollution with toxic metals such as aluminum ( $\mathrm{Al}$ ) limit the faba bean production (Abdelhamid et al., 2010). Consequently, faba bean growth and yield retardants should be investigated.

Aluminum abundance in the earth's crust is very high. In nature, the highest amount of $\mathrm{Al}$ is present in unsoluble form (aluminum silicate), but very small amount of $\mathrm{Al}$ is present in soluble form; this enters and affects biological systems (May and Nordstrom, 1991). The detected negative effects of $\mathrm{Al}$ on plant root tips were attributed to increase of cell wall rigidity, decrease of cell respiration and DNA replication, and interfere with cell division (Llugany et al., 1995). Some authors confirmed that root tips play a major role in $\mathrm{Al}$ toxicity/protection (Bennet and Breen, 1991), but others refuse this hypothesis (Ryan et al., 1993). In Al-sensitive maize cultivar, Al was accumulated in the distal transition zone of the root apex (1-2 mm) and inhibited root elongation (Sivaguru and Horst, 1998).

In plants, $\mathrm{Al}$ tolerance varies between species or cultivars of each one and it depends on detoxification of accumulated $\mathrm{Al}$ or prevention of $\mathrm{Al}$ uptake (Rengel, 1996). Aluminum toxicity is usually associated with chromosomal changes, which can be detected by karyologic analysis of Al-treated root tips by estimating mitotic indices (MI), micronucleus (MN) formation and chromosomal abnormalities (CA) (Yi et al., 2010; Kotelnikova et al., 2019). Faba bean could be used as a test species for monitoring the genotoxicity of Al because of its small number of chromosomes and their length make it easy to detect the damage occurring under the influence of the studied factor (Gopalan, 1999; Yi et al., 2010; Altwaty et al., 2016).

Induction of reactive oxygen species (ROS) formation under Al toxicity was reported (Rout et al., 2001) causing single and double strand DNA breaks. Consequently, the frequency of CA and MN is increased (Yi et al., 2010). In faba bean root tips, high concentrations of $\mathrm{Al}$ resulted in decreased MI, reduced mitotic activity and blocked DNA synthesis (Mohanty et al., 2004), and DNA recombination (Achary and Panda, 2010). Yi et al. (2010) reported that some mitotic cells could enter and continue mitotic cell division with abnormal DNA.

Chromosomal abnormalities due to abiotic stress agent could be detected not only by cytogenetic approach but also with molecular testing based on PCR. Chromosomal abnormalities as well as point mutations may result in alterations either at or between the RAPD or ISSR primer binding sites leading to alterations of the PCR products. These products can be used to calculate polymorphism which gives clear indication about the stability of the studied genome under the influence of the studied agent (Hassanein et al., 2018).

The data available so far on the toxic effects of high concentrations of $\mathrm{Al}$ on plant species are few. While relatively high concentrations of $\mathrm{AlCl}_{3}$ was used in our study (5- $25 \mathrm{mmol}$ for $24 \mathrm{~h}$ ), they were lower than what used by others (Karimai and Poozesh, 2016). Under relatively high concentrations of $\mathrm{AlCl}_{3}$, studies linking results of cytogenetical and molecular techniques are scarce. Consequently, the aim of this study was to investigate genome stability of two faba bean cultivars under the influence of relatively high dose of $\mathrm{AlCl}_{3}$ using cytogenetical and molecular techniques. Also, to know which of the easiest and cheapest molecular biology techniques, such as RAPD or ISSR, confirm the obtained cytogenetic data.

\section{MATERIAL AND METHODS}

In preliminary experiment, seeds of ten faba bean cultivars were obtained from Agriculture Research and Seeds Center in Qena, Egypt. Faba bean seeds were surface sterilized with $5 \%(\mathrm{v} / \mathrm{v})$ commercial sodium hypochlorite for $5 \mathrm{~min}$ followed by $0.2 \%(\mathrm{w} / \mathrm{v})$ mercuric chloride for $5 \mathrm{~min}$. Seeds were rinsed in sterilized deionized water 3 times, $10 \mathrm{~min}$ each. For seed germination, they were subjected to a series of $\mathrm{AlCl}_{3}$ concentrations (5, $10,15,20,25,30,35$ and $40 \mathrm{mmol}$ ) for different exposure times $(6,12$ and $24 \mathrm{hr})$. After ten days, seed germination and seedling growth parameters were estimated. Consequently, three $\mathrm{AlCl}_{3}$ concentrations $(5,15$ and $25 \mathrm{mmol}$ ) as well as the most tolerant ('Giza 843') and sensitive ('Nobaria 3') cultivars were used for further studies.

Seeds of 'Giza 843' and 'Nobaria 3' were selected to be homogeneous in size and color, and without wrinkles. Ten sterilized seeds were grown in sterilized petri dish contains filter paper and a thin layer of sterilized distilled 
water $(15 \mathrm{ml})$ for 2 to 3 days. Seedlings with root length of $2-3 \mathrm{~cm}$ were immersed in solution of $\mathrm{AlCl}_{3}$ of three concentrations $(5,15$ and $25 \mathrm{mmol})$ for three time periods $(6,12$ and $24 \mathrm{~h})$. Faba bean seeds treated with distilled water were used as control. In each treatment, three replicates were used, each with 10 seeds/Petri dish. Seeds were germinated under lab condition at $28 \pm 2{ }^{\circ} \mathrm{C}$. For each treatment, ten root tips were cut and fixed overnight in ethanol:acetic acid $3: 1(\mathrm{v} / \mathrm{v})$ at $4{ }^{\circ} \mathrm{C}$. Then, root tips were hydrolyzed with $1 \mathrm{~N} \mathrm{HCl}$, stained microsopic slides were prepared by at $60{ }^{\circ} \mathrm{C}$ for $8-10$ minutes. Then, roots were washed and transferred into the Feulgen stain for one hour. Root tips were teased out on clean slide, coated with egg-albumen, in a drop of $45 \%$ glacial acetic acid and they squashed between cover and slide. To separate covers, slides were turned face down in a Petri-dish containing distilled water. Plant materials were dehydrated using a series of ethyl alcohol (50\%, $70 \%, 96 \%)$ for 10 minutes in each alcohol concentration. The slides were immersed in a solution of absolute ethanol and xylol (1:1). Slides were cleared in pure xylol for 10 minutes, mounted in Canada balsam and transferred to dry in a hot air oven at $35-40{ }^{\circ} \mathrm{C}$ for $2-3$ days (Darlington and La Cour, 1976; Kanaya et al., 1994).

The percentage of MI, phase indexes, total abnormalities and the percentage of the aberrations were determined according to the following formulas:

Mitotic index (M.I.) $=($ No. of dividing cells $\mathrm{x} 100) /$ (No. of non dividing cells + No.of dividing cells)

Total abnormalities $=$ (No. of abnormal dividing cells $\mathrm{x} 100) /($ No. of dividing cells)

$\%$ of the phase $=($ No. of dividing cells in phase $\mathrm{x}$ $100) /($ No. of dividing cells)
The percentage of the aberrations $=($ No. of aberrant cells $\mathrm{x}$ 100)/( No. of dividing cells)

To determine the genetic variation and genome stability of root tips treated with $5 \mathrm{mM} \mathrm{AlCl}_{3}$ for different periods, the RAPD and ISSR techniques were used. DNA extraction was carried out three times of each treatment and according to the method of Porebski et al. (1997). Hexadecyl trimethyl ammonium bromide (CTAB) procedure based on the protocol of Porebski et al. (1997) was used. Frozen root tissues $(200 \mathrm{mg}$ ) were ground using $1000 \mu \mathrm{l}$ of CTAB buffer. The obtained homogenate was mixed gently with $2 \mu \mathrm{l}$ of RNAse, incubated at $65^{\circ} \mathrm{C}$ for $90 \mathrm{~min}$ and centrifuged at $10000 \mathrm{rpm}$ for $5 \mathrm{~min}$. Supernatant was transferred to a new tube, where $500 \mu$ of 24:1 chloroform-isoamyl alcohol were add and mixed well by shaking. The mixture was centrifuged at $10000 \mathrm{rpm}$ for 5 min, and the aqueous phase (top) was quickly measured and isolated. Then, one volume of cold isopropanol was added. Samples were let to sit at $-20{ }^{\circ} \mathrm{C}$ for $45-60 \mathrm{~min}$. Samples were centrifuged for $10 \mathrm{~min}$ at 12000 and supernatant was carefully removed without disturbing the resultant DNA pellet. Then, $700 \mu$ of cold $70 \%$ ethanol were added, inverted once to mix and centrifuged for 1 min at $12000 \mathrm{rpm}$. The DNA pellet was dried at $55^{\circ} \mathrm{C}$, resuspended in $100 \mu \mathrm{l}$ of TE buffer and allowed to resuspend for $1 \mathrm{hr}$ at $55^{\circ} \mathrm{C}$ before use.

A total of ten RAPD and nine ISSR primers (Table 1) were used to analyze genome stability of Al treated roots. The obtained genomic DNA was amplified using Thermal Cycler (Biometra TPersonal Combi, Biometra $\mathrm{GmbH}$, Germany). The RAPD and ISSR reactions were performed in a $25 \mu \mathrm{l}$ volume containing $12.5 \mu \mathrm{l}$ of Go $\mathrm{Taq}^{\oplus}$ Green Master Mix (Promega, Madison, USA), $3 \mu \mathrm{l}$ of primer $10 \mathrm{pmol}, 6.5 \mu \mathrm{l}$ of free nuclease water and $3 \mu \mathrm{l}$ of $100 \mathrm{ng}$ genomic DNA templates.

Table 1: The applied RAPD and ISSR primers

\begin{tabular}{llll}
\hline RAPD Primer & $\begin{array}{l}\text { Primer Sequence } \\
\left(5^{\prime}------3^{\prime}\right)\end{array}$ & ISSR Primer & $\begin{array}{l}\text { Primer Sequence } \\
\left(5^{\prime}-----^{\prime}\right)\end{array}$ \\
\hline OPA-02 & TGCCGAGCTG & ISSR1 & ACACACACACACACACCTG \\
OPA-05 & AGGGGTCTTG & ISSR2 \\
OPA-07 & GAAACGGGTG & ISSR3 & ACACACACACACACAAAGCT \\
OPA-17 & GACCGCTTGT & ISSR4 & GAGAGAGAGAGAGAGACTG \\
OPat-08 & TCCTCGTGGG & ISSR5 & GAGAGAGAGAGAGAGACTC \\
OPaw-10 & GGTGTTTGCC & ISSR7 & CTCTCTCTCTCTA (CT)6A \\
OPD-1 & ACCGCGAAGG & ISSR8 & TCTTCTTCTTCTG \\
OPD-18 & GAGAGCCAAC & ISSR9 & TGTTGTTGTGC \\
OPJ-15 & TGTAGCAGGG & ISSR10 & GTGGTGGTGGC \\
OPP-13 & GGAGTGCCTC & & \\
\hline
\end{tabular}


The program of PCR amplification was applied with initial denaturation cycle at $94{ }^{\circ} \mathrm{C}$ for five minutes. The next 40 cycles were carried out using denaturation step at $94{ }^{\circ} \mathrm{C}$ for $45 \mathrm{sec}$, annealing step (optimized for each primer), and elongation step at $72^{\circ} \mathrm{C}$ for $1 \mathrm{~min}$. Finally, extension step was performed at $72{ }^{\circ} \mathrm{C}$ for $7 \mathrm{~min}$. The obtained PCR products were subjected to electrophoresis using $1.5 \%$ or $2 \%$ agarose gel with ethidium bromide $\left(0.5 \mu \mathrm{g} \mathrm{ml}^{-1}\right)$. Run was carried out in $1 \mathrm{X}$ TBE buffer at 70 volts. The amplified PCR products were visualized and photographed. Polymorphic, monomorphic, unique, total and molecular weight of each band were determined.

Reproducibility was taken in consideration to minimize personal errors. In this concern, each primer was used three times under the same PCR conditions. The DNA banding patterns obtained from amplification of the studied genome using RAPD and ISSR primers were analyzed by a computer program; Gene Profiler (version 4.03). Microsoft excel file was prepared for scoring the data as ' 1 ' for matched and ' 0 ' for the unmatched of DNA band. Monomorphic, polymorphic and unique bands were taken into consideration to calculate polymorphism of each primer to determine the number of events leading to alteration of primer binding sites on the genome under the toxic effect of $\mathrm{Al}$ compared to control plants. Dendrograms were generated for cluster analysis according to Legendre and Legendre (1983) using the Community Analysis Package Software Program (CAP) Version 4.0 (Richard and Peter, 2007).

\section{$3 \quad$ RESULTS}

Depending on data of preliminary seed germination and seedling growth, 'Giza 843' was found to be the most tolerant but 'Nobaria 3' was the most sensitive faba bean cultivar to $\mathrm{AlCl}_{3}$. Cultivar 'Nobaria 3' recorded the highest decrease of root growth parameters, where they were $5.71 \%, 74.29 \%$ and $77.14 \%$ for root lengths, $53.41 \%$, $80.68 \%$ and $87.50 \%$ for fresh mass, and $50 \%, 75 \%$ and $75 \%$ for dry mass under the treatment with 5,15 and $25 \mathrm{mmol} \mathrm{AlCl}_{3}$, respectively. Under these conditions, 'Giza 843' recorded increased fresh (6\%) and dry mass (22\%) but reduced shoot length $(3.3 \%)$ when $5 \mathrm{mmol}$ $\mathrm{AlCl}_{3}$ was used. In addition, 'Giza 843 ' showed reduced root growth parameters where they were $68.85 \%$ and $72.13 \%$ for root length, $53.76 \%$ and $68.82 \%$ for fresh mass, and $44.44 \%$ and $66.67 \%$ for dry mass of 15 and $25 \mathrm{mmol} \mathrm{AlCl}_{3}$, respectively

Aluminum chloride caused a significant decrease in the mitotic activities in treated root tips of 'Giza 843' or 'Nobaria 3' cultivars (Tables 2 and 4) when they were treated with different concentrations of $\mathrm{AlCl}_{3}$ for dif- ferent time periods. Data of MI indicate that 'Giza 843' was the least affected when root tips were subjected to different concentrations of $\mathrm{AlCl}_{3}$ for $6 \mathrm{hr}$. For example, under the influence of the lowest concentration of $\mathrm{AlCl}_{3}(5 \mathrm{mmol})$ and the shortest exposure time $(6 \mathrm{~h}), \mathrm{MI}$ of 'Giza $843^{\prime}$ (2.70) was higher than that of 'Nobaria 3' (1.87). The same was observed when the highest concentration of $\mathrm{AlCl}_{3}$ (25 mmol) was used for $6 \mathrm{hr}$. MI of 'Giza 843' (3.10) was higher than that of 'Nobaria 3' (2.60). The lowest MI values were detected when root tips of both cultivars were subjected to different $\mathrm{Al}$ concentrations for $24 \mathrm{hr}$. In 'Giza 843', complete inhibition of mitotic cell activities was detected when the highest concentration of $\mathrm{Al}\left(25 \mathrm{mmol} \mathrm{AlCl}_{3}\right)$ for the longest time of exposure (24 hr) was used.

In comparison to that of control $\left(\mathrm{AlCl}_{3}\right.$-untreated plants), the increase in $\mathrm{AlCl}_{3}$ concentration or exposure time led to significant increase in the values of interphase and it associated with significant increase in total chromosomal abnormalities in both cultivars (Table 2 and 4). In addition, while the highest values of interphase were detected under $25 \mathrm{mmol} \mathrm{Al}$ for $24 \mathrm{hr}$, prophase stage was inhibited completely in both cultivars. In 'Giza 843', when the $\mathrm{AlCl}_{3}$ exposure time was $6 \mathrm{hr}$, total abnormalities increased with the increase of $\mathrm{Al}$ concentrations. In additions, when the concentration of $\mathrm{AlCl}_{3}$ was $5 \mathrm{mmol}$, total abnormalities increased with the increase of exposure time. Under the influence of all $\mathrm{AlCl}_{3}$ concentrations for 6 or $12 \mathrm{~h}$, total abnormalities of 'Giza $843^{\text {' }}$ were lower than those of 'Nobaria 3'. While total mitosis and MI drastically decreased under $\mathrm{AlCl}_{3}$ treatments for 24 h, high total chromosomal abnormalities were detected in both cultivars. The frequency of abnormalities in all mitotic phases increased under $\mathrm{AlCl}_{3}$ treatments in both cultivars.

In both cultivars, the frequency of $\mathrm{MN}$ increased under the influence of all $\mathrm{AlCl}_{3}$ treatments, this increase was lower in 'Giza 843' than 'Nobaria 3' (Tables 3 and 5 ). Cells with one, two or more micronuclei appeared in both cultivars (Fig. 1).

All $\mathrm{AlCl}_{3}$ concentrations induced chromosomal abnormalities at all stages of mitosis; depended on the used cultivar. While the frequency of C-metaphase in 'Giza $843^{\prime}$ was higher than 'Nobaria 3', vice versa was detected in case of C-anaphase (Table 3 and Table 5). On the other side, the frequency star chromosomes in metaphase of 'Giza 843' (Table 3) was lower than that of 'Nobaria 3', vice versa was detected during ana-telophase. In addition, under the influence of different $\mathrm{AlCl}_{3}$ treatments, the frequency of different abnormalities was higher in 'Nobaria 3' than 'Giza 843'. For example, the frequencies of chromosomal breaks and sticky and disturbed chromosomes during metaphase or ana-telophase in 'No- 


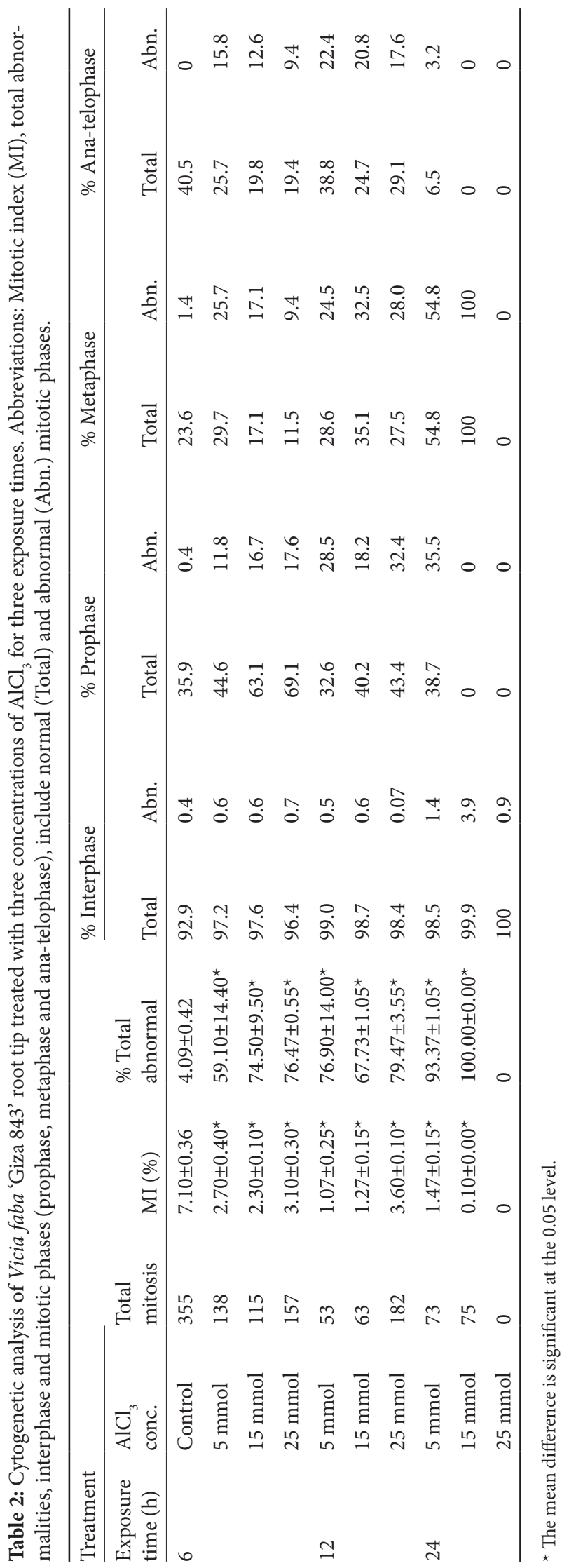

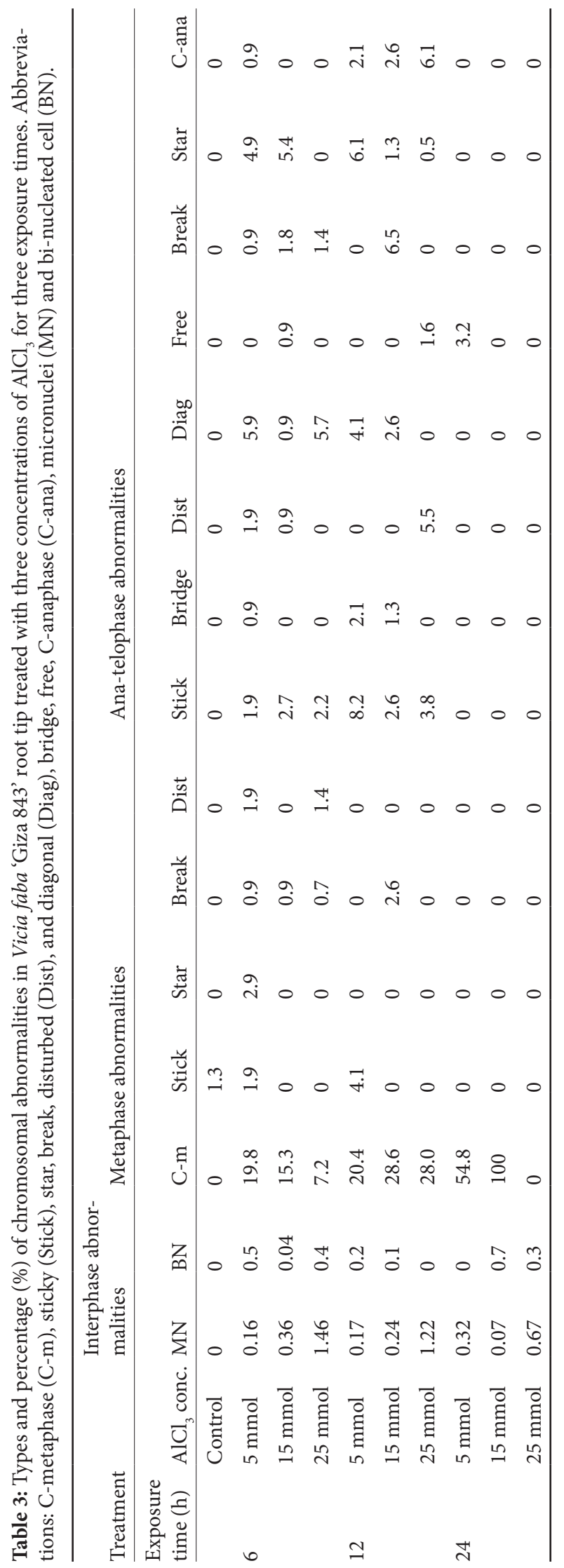



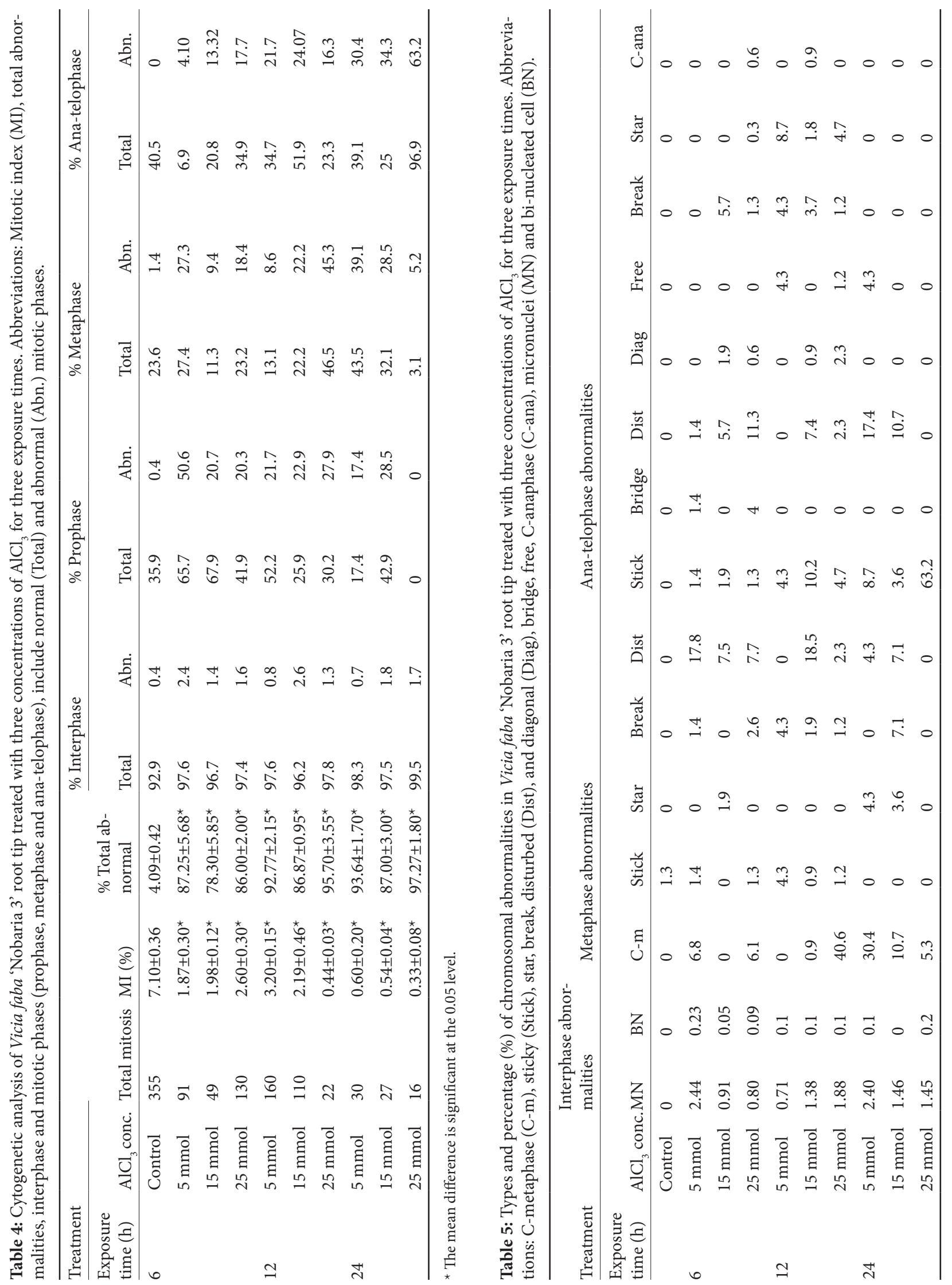

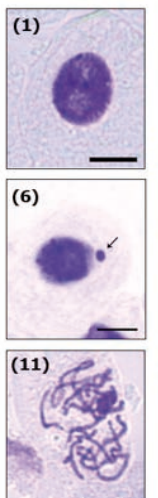

(16)

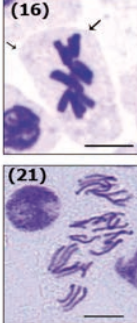

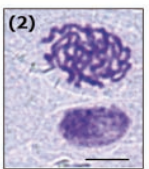
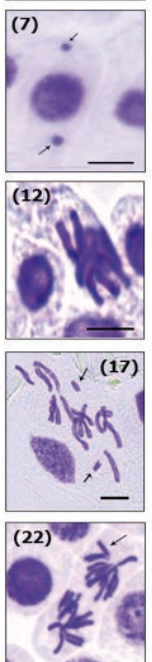
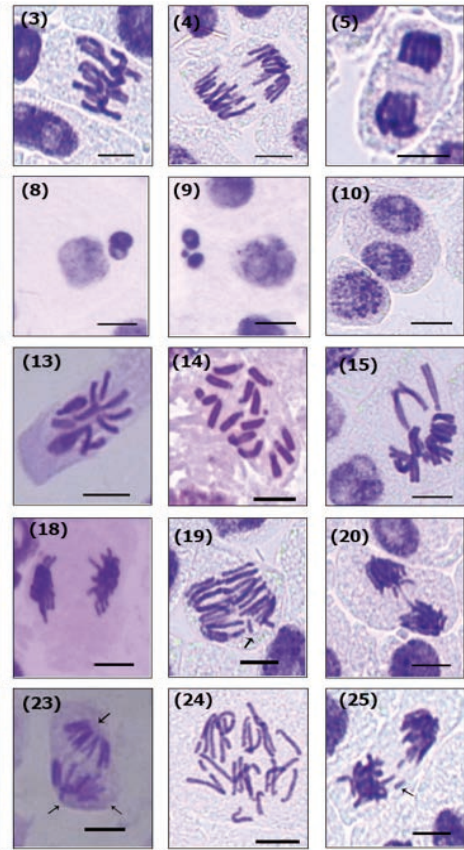

Figure 1: Chromosomal aberrations in Vicia faba 'Giza 843 and Nobaria 3' root tips under the influence of $\mathrm{AlCl}_{3}$ : interphase (1), prophase (2), metaphase (3), anaphase (4), telophase (5), micronuclei with different sizes and different number $(6,7,8,9)$, binucleated cell (10), irregular prophase (11), sticky metaphase (12), star metaphase (13), C-metaphase (14), dis 5rturbed metaphase (15), diagonal metaphase (16), metaphase break (17), sticky anaphase (18), anaphase break (19), anaphase bridge (20), C-anaphase (21), anaphase with free chromosome (22), diagonal anaphase (23), disturbed anaphase (24) and sticky anaphase break (25). The scale bar equals $10 \mu \mathrm{m}$.

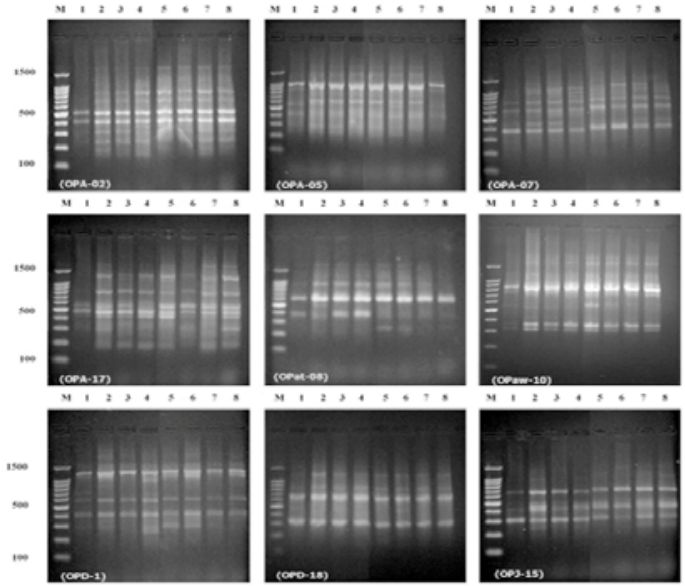

Figure 2: RAPD profile generated by 9 primers using roots of two Vicia faba cultivars treated with 5 mmol $\mathrm{AlCl}_{3}$ for different periods. Lanes 1, 2, 3 and 4: 'Giza 843' for 0 (control), 6, 12 and 24 h, respectively. Lanes 5, 6, 7 and 8: 'Nobaria 3' for 0 (control) 6, 12 and $24 \mathrm{~h}$, respectively. M: DNA ladder.

baria 3' cells were higher those of 'Giza 843'. In concern to ana-telophase abnormalities, the frequency of diagonal chromosomes under different $\mathrm{AlCl}_{3}$ treatments was higher in 'Giza 843' than in 'Nobaria 3' (Tables 3 and 5). In comparison to other chromosomal abnormalities, free chromosomes appeared in low frequency in both culti- vars (Table 3 and Table 5); it never appeared when low concentration of $\mathrm{AlCl}_{3}$ in combination with short exposure time was applied.

Root tips treated with $5 \mathrm{mmol} \mathrm{AlCl}_{3}$ for different periods were subjected to molecular analysis using RAPD (Table 6) and ISSR primers (Table 7). When ten RAPD 


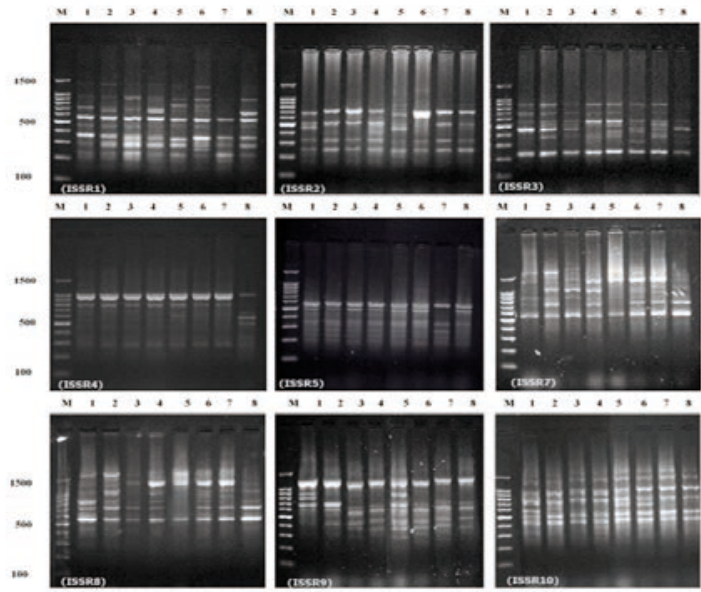

Figure 3: ISSR profile generated by 9 primers using roots of two Vicia faba cultivars treated with $5 \mathrm{mmol} \mathrm{AlCl}_{3}$ for different periods. Lanes 1, 2, 3 and 4: 'Giza' 843 for 0 (control), 6, 12 and 24 h, respectively. Lanes 5, 6, 7 and 8: 'Nobaria 3' for 0 (control) 6, 12 and 24 h, respectively. M: DNA ladder.

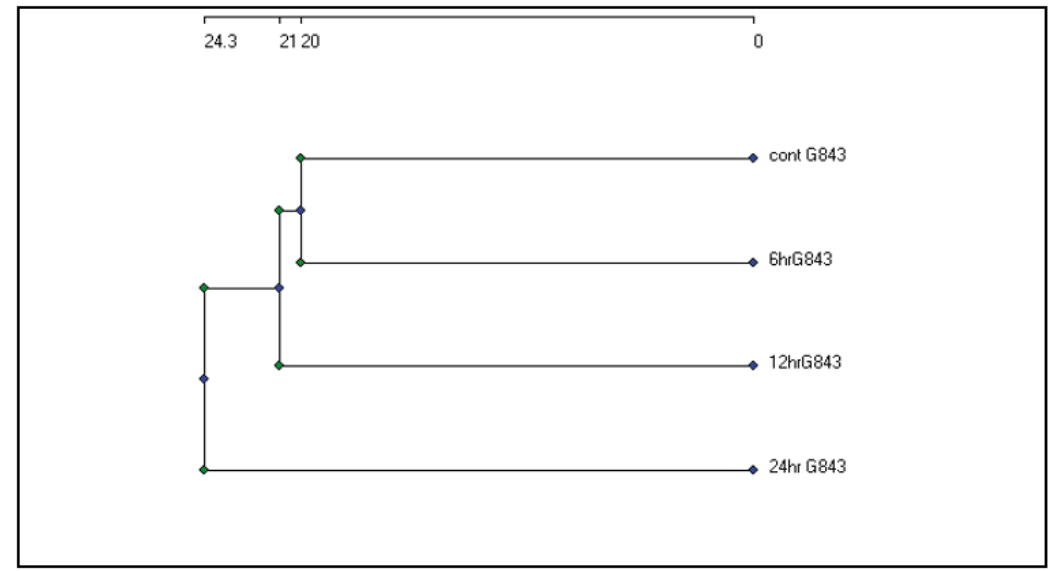

Figure 4: UPGMA based cluster tree of Vicia faba 'Giza 843' exposed to $5 \mathrm{mmol} \mathrm{AlCl}_{3}$ for 6, 12 and $24 \mathrm{~h}$ based on ten RAPD and nine ISSR primers.

primers were used for amplification of genomic DNA of two faba bean cultivars ('Giza 843' and 'Nobaria 3'), different profiles were obtained (Table 6; Fig. 2). They expressed 27 and 26 polymorphic, 20 and 20 monomorphic, 8 and 10 unique out of total 55 and 56 bands when genomes of 'Giza 843' and 'Nobaria 3' were amplified, respectively. Consequently, while percentage of polymorphism ranged from $0 \%$ (OPD-18) to $85.72 \%$ (OPA-17) with an average of $61.74 \%$ in 'Giza 843 ', they ranged from $20 \%$ (OPD-18) to $90.91 \%$ (OPA-17) with an average of $61.24 \%$ in 'Nobaria 3'.

The applied ISSR primers on 'Giza 843' genome resulted in amplification of 38 polymorphic out of 69 fragments $(55.07 \%)$, they included 18 monomorphic, 9 unique and 38 polymorphic bands (Table 7; Fig. 3). Consequently, the percentage of polymorphism in 'Giza $843^{\text {c }}$
PCR products ranged from $25 \%$ (ISSR5 or ISSR10) to $100 \%$ (ISSR9) with an average of $65.36 \%$; it was higher than that of RAPD primers. When root tips of 'Nobaria 3 ' were subjected to $\mathrm{AlCl}_{3}$ for different periods using ISSR primers, 72 fragments were amplified including 22 monomorphic, 7 unique and 43 polymorphic bands. Percentage of polymorphism ranged from $25 \%$ (ISSR5) to $100 \%$ (ISSR9) with an average of $71.59 \%$; it was higher than that of RAPD primers.

Cluster tree based on ten RAPD and nine ISSR primers of 'Giza $843^{\text {' }}$ cultivar resulted in grouping of control plant with others subjected to $5 \mathrm{mmol} \mathrm{Al}$ for 6 or 12 $\mathrm{h}$ (Fig. 4). On the other side, the dendrogram of 'Nobaria 3 ' included two main clusters; the first cluster contained control plants and others subjected to $\mathrm{AlCl}_{3}$ for $6 \mathrm{~h}$. The 

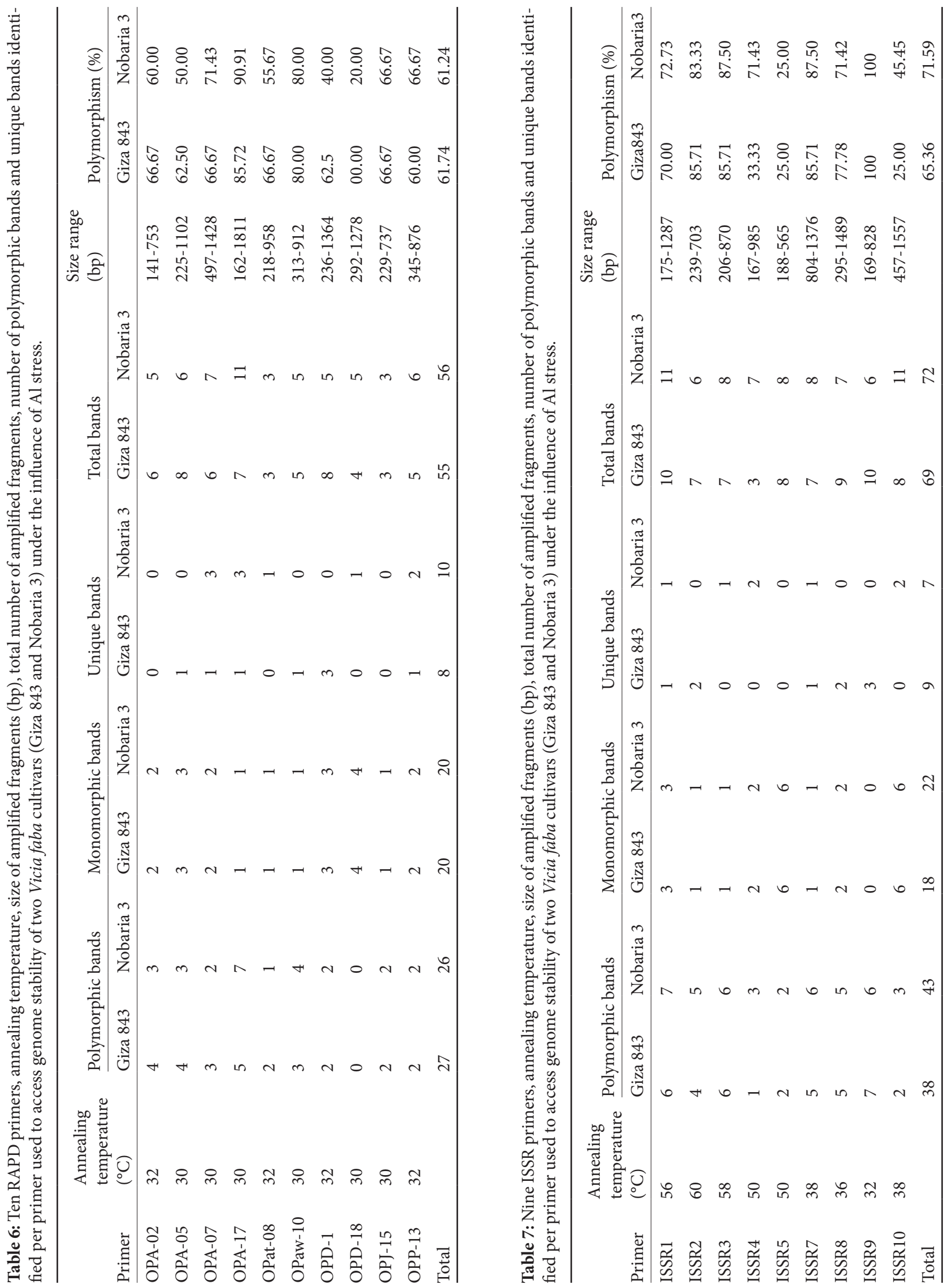


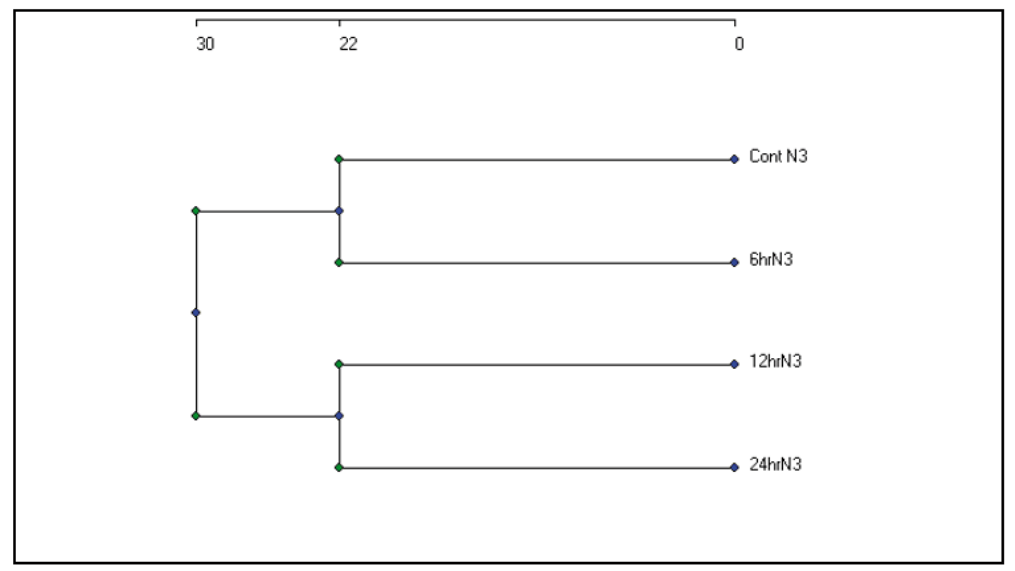

Figure 5: UPGMA based cluster tree of Vicia faba 'Nobaria 3' exposed to $5 \mathrm{mmol} \mathrm{AlCl}_{3}$ for 6, 12 and $24 \mathrm{~h}$ based on ten RAPD and nine ISSR primers.

second cluster included plants subjected to $\mathrm{AlCl}_{3}$ for 12 or $24 \mathrm{~h}$ (Fig. 5).

\section{DISCUSSION}

When seed were germinated and subjected to $\mathrm{AlCl}_{3}$ concentrations, they showed retardation of seed germination and seedling growth, which were lower in 'Giza

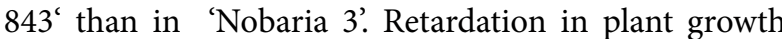
under the influence of $\mathrm{Al}$ toxicity could be attributed to DNA damage (Achary and Panda, 2010), inhibition of cell division and elongation (De Campos and Viccini (2003), stimulation of oxidative stress (Rout et al., 2001 ), inhibition of water movement through roots, and retardation of root development and the ability of plants to develop symbiosis (Aroca et al., 2007; Belachew and Stoddard, 2017). Consequently, aluminum toxicity exacerbates the effects of other abiotic stresses (Muktadir et al., 2020). Seedlings were used in this study because they are more susceptible to $\mathrm{AlCl}_{3}$ than older plants (Thawornwong and van Diest, 1974) especially when relatively high concentration of $\mathrm{AlCl}_{3}$ was used. Aluminum toxicity on faba bean cultivars as well as other plant species was reported (Rout et al., 2001; Yi et al., 2010; Altwaty et al., 2016), but its effect varies within plant species and genotypes (Rengel, 1996). To mimic many unfertile acid

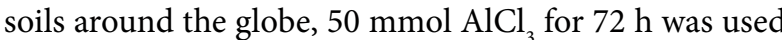
to test germplasm sensitivity to $\mathrm{Al}$ toxicity (Domingues et al., 2013). In our study, high concentrations of $\mathrm{Al} \mathrm{Cl}_{3}$ up to $25 \mathrm{mmol}$ were used for cytogenetic studies. Under these conditions, seedling growth of 'Giza 843' was less influenced by $\mathrm{AlCl}_{3}$ than 'Nobaria 3'.

Aluminum chloride caused a significant decrease in mitotic activities of root tip cells of 'Giza 843' and 'No- baria 3'. The reduction in MI of 'Giza 843' was lower than that of 'Nobaria 3' indicating that 'Giza 843' was more Al-tolerant than 'Nobaria 3'. The obtained data indicate that $\mathrm{Al} \mathrm{Cl}_{3}$ induced cell cycle defects in faba bean root cells (Zhang et al., 2009; Yi et al., 2010). The lowest values of MI were detected when the highest concentration of $\mathrm{AlCl}_{3}(25 \mathrm{mmol}$ was used for $24 \mathrm{~h}$ leading to the complete inhibition of cell division in 'Giza 843'. Inhibition of mitotic cell cycle was attributed to the retardation of cell cycle during interphase (Mohandes and Grant, 1972), decline of energy resources (Rost and Morrison, 1984), inhibition of transition from G1 to S and G2 ( $\operatorname{Van}^{\prime}$ $\mathrm{t}$ Hoff,1985) and binding of $\mathrm{Al}$ on DNA molecules (Matsumoto et al., 1976).

While total mitosis and MI drastically decreased, total abnormalities increased in both cultivars when they were subjected to $\mathrm{AlCl}_{3}$ for 6 or $12 \mathrm{~h}$. Under these conditions, total abnormalities in 'Giza 843' were lower than those of 'Nobaria 3', which may be due to lower abnormalities in prophase and ana-telophase stages, especially under the influence of the lowest exposure period. Increased exposure time to $\mathrm{AlCl}_{3}$ for more than $6 \mathrm{~h}$ resulted in irregular trends of the obtained data. Under $\mathrm{Al}$ stress, cell divisions in faba bean root tips was often associated with reduction in genomic template stability and an increase in RAPD band frequencies (Rout et al., 2001; Taspinar et al., 2018). Hartig and Beck (2006) confirmed the survival of the stressed cells if they tolerated the occurred mutation (Hartig and Beck, 2006). In both cultivars, while frequency of interphase was very high under the highest $\mathrm{Al}$ treatment $(25 \mathrm{mmol}$ for $24 \mathrm{~h}$ ), the prophase was inhibited completely in this study and others (Yi et al., 2010).

The frequency of $\mathrm{MN}$ increased under the influence of all $\mathrm{AlCl}_{3}$ treatments, this increase was lower in 'Giza 
$843^{\prime}$ than 'Nobaria 3'. Micronuclei formation was used as an effective tool to measure of chromosomal DNA damages and analyzes the mutagenic effect of chemicals (Fenech, 2008). These studies indicated that some of the cells enter the mitotic cell division with damaged DNA (Hartig and Beck, 2006). Under stress conditions, positive correlation was detected between chromosomal abnormalities and $\mathrm{MN}$, and antioxidant enzymes and lipid peroxidation (Souguir et al., 2011). Since 'Giza 843' had less micronuclei and chromosomal abnormalities than 'Nobaria 3' under $\mathrm{AlCl}_{3}$ stress, 'Giza '843' was considered more tolerant to Al than 'Nobaria 3' cultivar.

While several types of chromosomal abnormalities at all stages of mitosis were detected under $\mathrm{AlCl}_{3}$ treatments, they depended on the used cultivar. The most common types of these abnormalities were bridges, laggards, fragments and micronuclei as was reported by $\mathrm{Yi}$ et al. (2010). Under the influence of different $\mathrm{AlCl}_{3}$ treatments, frequencies of appearance of different abnormalities including C-anaphase, star metaphase chromosomes, and breaks, sticky and disturbed chromosomes during metaphase or anaphase were higher in 'Nobaria 3 ' than those of 'Giza 843'. Our data confirmed that $\mathrm{Al}$ is a genotoxic and cytotoxic reagent in plant cells leading to chromosomal abnormalities in several forms (Yi et al., 2010).

Under the toxic effect of $\mathrm{AlCl}_{3}$, changing the frequency of primers binding loci increased as cytogenetical events increased; which could be identified by the values of the obtained polymorphism. When ten of RAPD primers were used for amplification of genomic DNA of 'Giza 843' and 'Nobaria 3', the polymorphism average $61.74 \%$ in 'Giza 843' and $61.24 \%$ in 'Nobaria 3'. Link et al. (1995) confirmed that RAPD was useful molecular markers to study genetic variation in faba beans. In our work, application of RAPD technique to detect genetic variation due to $\mathrm{Al}$ treatments in faba bean was not recommended.

Application of ISSR primers on 'Giza 843' and 'Nobaria 3' genomes resulted in amplification of 69 and 72 fragments, respectively. ISSR technique was efficiently used for classifying faba bean and other plant species (Abdel-Razzak et al., 2012; Salem and Hassanein, 2017; Hassanein et al., 2018). The calculated polymorphism average of ISSR primers of 'Giza $843^{\text {' }}$ was lower than that of 'Nobaria 3' indicating that 'Giza 843' genome was more stable than that of Nobaria 3 under Al stress. The detected DNA polymorphism may be due to mismatching at the primer site, appearance of a new primer site and/ or change the distance between two opposite primers. These events may result from point, and chromosomal mutations/abnormalities (Kumar and Rai, 2006). Consequently, these events could be detected by cytogenetical techniques (through micronuclei formation and chromosomal abnormalities) or molecular techniques such as ISSR (through polymorphism average). Data obtained from both techniques confirmed that $\mathrm{Al}$ tolerance of 'Giza 843' was higher than that of 'Nobaria 3'. ISSR was efficiently used to detect variation in faba bean (AbdelRazzak et al., 2012). Combination of cytogenetical and molecular techniques for efficient evaluation of genetic variation in plants was recommended in this study and others (Begum and Alam, 2017; Hossain et al., 2017).

Construction of dendrograms depending on the data of molecular techniques and study of their details supplemented us with another evidence confirmed the harmony between cytogenetical and molecular biology techniques as well as seedling growth parameters. The obtained cluster tree of 'Giza 843' grouped of control plant with others subjected to $5 \mathrm{mmol} \mathrm{Al}$ for 6 or $12 \mathrm{hr}$. On the other side, the cluster tree of 'Nobaria 3' grouped control plants with only others subjected to $5 \mathrm{mmol} \mathrm{AlCl}_{3}$ for 6 hr. Comparison between the two obtained dendrograms, polymorphism and cytogenetical data indicated that 'Giza 843' tolerated Al more than 'Nobaria 3'.

\section{REFERENCES}

Abdelhamid M. T., Shokr M. M. B. \& Bekheta M. A. (2010). Growth, root characteristics, and leaf nutrients accumulation of four faba bean (Vicia faba L.) cultivars differing in their broomrape tolerance and the soil properties in relation to salinity. Communication Soil Science of Plant Analysis, 41, 2713-2728. https://doi.org/10.1080/00103624.2010 .518263

Abdel-Razzak H. S., Alfrmawy A. M., Ibrahim H. M. \& ElHanafy A. A. (2012). Genetic diversity in faba bean (Vicia faba L.) using Inter-Simple Sequence Repeat (ISSR) markers and protein analysis. Life Science Journal, 9, 497-503.

Achary V. M. M. \& Panda B. B. (2010). Aluminium-induced DNA damage and adaptive response to genotoxic stress in plant cells are mediated through reactive oxygen intermediates. Mutagenesis, 25(2), 201-209. https://doi.org/10.1093/ mutage/gep 063

Altwaty N. H., El-Sayed O. E., Aly N. A. H., Baeshen M. N. \& Baeshen N. A. (2016). Molecular and cytogenetic assessment of Dipterygium glaucum genotoxicity. Anais da Academia Brasileira de Ciências, 88, 623-634. https://doi. org/10.1590/0001-3765201620150208

Aroca, R.; Porcel, R. \& Ruiz-Lozano, J. M. (2007). How does arbuscular mycorrhizal symbiosis regulate root hydraulic properties and plasma membrane aquaporins in Phaseolus vulgaris under drought, cold or salinity stresses? New Phytolologist, 173, 808-816. https://doi.org/10.1111/j.14698137.2006.01961.x

Begum K. N. \& Alam S. S. (2017). Karyotype, RAPD and ISSR analysis of four specimens in Gynura nepalensis DC. Cy- 
tologia, 82(4), 423-428. https://doi.org/10.1508/cytologia.82.423

Belachew, K.Y. \& Stoddard, F. L. (2017). Screening of faba bean (Vicia faba L.) accessions to acidity and aluminium stresses. PeerJ. 5, e2963. https://doi.org/10.7717/peerj.2963

Bennet R. J. \& Breen CM (1991). The aluminium signal: New dimensions to mechanisms of aluminium tolerance. Plant Soil, 134, 153-166. https://doi.org/10.1007/BF00010728

Darlington C. D. \& La Cour L. F. (1976). The handling of chromosomes, 6th ed. George Allen and Unwin Ltd., London.

De Campos J. M. S. \& Viccini L. F. (2003) Cytotoxicity of aluminum on meristematic cells of Zea mays and Allium cepa. Caryologia, 56, 65-73. https://doi.org/10.1080/00087114.2 003.10589309

Domingues A. M., da Silva F., Freitas G., Ganança G. F., Nóbrega H., Slaski J. J. \& de Carvalho M. A. P. (2013). Aluminium tolerance in bean traditional cultivars from Madeira. Revista de Ciências Agrárias, 36(2), 148-156.

Duc G, Bao SY, Baum M \& Redden B. (2010). Diversity maintenance and use of Vicia faba L. genetic resources. Field Crops Research, 115, 270-278. https://doi.org/10.1016/j. fcr.2008.10.003

Fenech M. (2008). The micronucleus assay determination of chromosomal level DNA damage. Methods of Molecular Biology, 410, 185-216. https://doi.org/10.1007/978-1-59745548-0_12

Gopalan, H.N.B. 1999. Ecosystem health and human wellbeing: the mission of the International Program on Plant Bioassays. Mutation Research, 426, 99-102. https://doi. org/10.1016/S0027-5107(99)00048-2

Hartig K. \& Beck E. (2006). Crosstalk between auxin, cytokinins, and sugars in the plant cell cycle. Plant Biology, 8, 389-396. https://doi.org/10.1055/s-2006-923797

Hassanein A. M., Salem J. M., Faheed F. A. \& El-nagish A. (2018). Effect of anti-ethylene compounds on isoenzyme patterns and genome stability during long term culture of Moringa oleifera. Plant Cell Tissue Organ Culture, 132, 201212. https://doi.org/10.1007/s11240-017-1326-0

Hossain, A., Afroz, M., Sultana, S. S. \& Alam S.S. (2017). Karyotype and RAPD Diversity in Four Varieties of Gossypium hirsutum L. Cytologia, 82(5), 535-541. https://doi. org/10.1508/cytologia.82.535

Kanaya N. 1., Gill B. S., Grover I. S., Murin A., Osiecka R., Sandhu S. S. \& Andersson H. C. (1994). Vicia faba chromosomal aberration assay. Mutation Research, 310(2), 231-247. https://doi.org/10.1016/0027-5107(94)90116-3

Karimaei M. \& Poozesh V. (2016). Effects of aluminum toxicity on plant height, total chlorophyll $(\mathrm{Chl} \mathrm{a}+\mathrm{b})$, potassium and calcium contents in spinach (Spinacia oleracea L.). International Journal of Farming and Allied Sciences, 5(2), 76-82.

Kotelnikova A., Fastovets I., Rogova O., Volkov D. S. \& Stolbova V. (2019). Toxicity assay of lanthanum and cerium in solutions and soil. Ecotoxicology and Environmental Safety, 167, 20-28. https://doi.org/10.1016/j.ecoenv.2018.09.117

Kumar G. \& Rai P. (2006). Partial genome elimination through micronuclei in soybean (Glycine max). National Academy Science Letters, 29, 417-421.

Legendre L. \& Legendre P. (1983). Numerical ecology: developments in environmental modelling. Amsterdam, The Neth- erlands, pp 419. https://doi.org/10.1007/978-3-642-690242_56

Link W., Dexkins C.,, 3. Elsevier,

Singh M., Schwall M. \& Melschinmer A. E. (1995). Genetic diversity in European and Mediterranean faba beans germplasm revealed by RAPD markers. Theoretical and Applied Genetics, 90, 27-32. https://doi.org/10.1007/BF00220992

Llugany M., Poschenrieder C. \& Barcelo J. (1995). Monitoring of aluminium-induced inhibition of root elongation in four maize cultivars differing in tolerance to aluminium and proton toxicity. Physiologia Plantarum, 93, 265-271. https://doi.org/10.1111/j.1399-3054.1995.tb02227.x

Matsumoto H., Hirasawa E., Torikai H. \& Takahashi E. (1976) Localization of absorbed $\mathrm{Al}$ in pea root and its binding to nucleic acids. Plant and Cell Physiology, 17(1),127-137. https://doi.org/10.1093/oxfordjournals.pcp.a075252

May H. M. \& Nordstrom D. K. (1991). Assessing the solubilities and reaction kinetics of aluminous minerals in soils. In: Soil acidity. Springer Berlin Heidelberg, Berlin, Heidelberg, pp. 125-148. https://doi.org/10.1007/978-3-642-74442-6_6

Mohandas T. \& Grant W. F. (1972). Cytogenetic effects of 2,4-d and amitrole in relation to nuclear volume and DNA content in some higher plants. Canadian Journal of Genetics and Cytology, 14(4), 773-783. https://doi.org/10.1139/g72095

Mohanty S., Das A., Das P. \& Mohanty P. (2004). Effect of a low dose of aluminum on mitotic and meiotic activity, 4C DNA content, and pollen sterility in rice, Oryza sativa L. cv. Lalat. Ecotoxicology and Environmental Safety, 59, 70-75. https:// doi.org/10.1016/j.ecoenv.2003.07.017

Muktadir M. A., Adhikari K. N., Merchant A., Belachew K.Y., Vandenberg A., Stoddard F. L. \& Khazaei H. (2020). Physiological and Biochemical Basis of Faba Bean Breeding for Drought Adaptation. Agronomy, 10, 1345; https://doi. org/10.3390/agronomy10091345

Porebski S., Bailey L. G. \& Baum B. R. (1997). Modification of a CTAB DNA extraction protocol for plants containing high polysaccharide and polyphenol components. Plant Molecular Biology Reports, 15, 8-15. https://doi.org/10.1007/ BF02772108

Rengel Z. (1996). Uptake of aluminium by plant cells. New Phytologist, 134, 389-406. https://doi. org/10.1111/j.1469-8137.1996.tb04356.x

Richard S. \& Peter H. (2007). Community Analysis Package 4.0. Searching for structure in community data. Printed in Lymington, UK.

Rost T. L. \& Morrison S. L. (1984). The comparative cell cycle and metabolic effects of chemical treatments on root tips meristems. II. Propham, chloropropham and 2,4-dinitophenol. Cytologia, 49, 61-72. https://doi.org/10.1508/cytologia. 49.61

Rout G. R., Samantaray S. \& Das P. (2001). Aluminium toxicity in plants: a review. Agronomie, 21, 3-21. https://doi. org/10.1051/agro:2001105

Ryan P., Ditomaso J. M. \& Kochian V. (1993). Aluminium toxicity in roots: an investigation of spatial sensitivity and the role of the root cap. Journal of Experimental Botany, 44 (2), 437-446. https://doi.org/10.1093/jxb/44.2.437

Salem J. \& Hassanein A. M. (2017). In vitro propagation, mi- 
crotuberization, and molecular characterization of three potato cultivars. Biologia Plantarum, 61, 427-437. https:// doi.org/10.1007/s10535-017-0715-x

Sivaguru M. \& Horst W. J. (1998). The distal part of the transition zone is the most aluminum-sensitive apical root zone of maize. Plant Physiology, 116, 155-163. https://doi. org/10.1104/pp.116.1.155

Souguir D, Ferjani E, Ledoigt G, Goupil P (2011) Sequential effects of cadmium on genotoxicity and lipoperoxidation in Vicia faba roots. Ecotoxicology, 20, 329-336. https://doi. org/10.1007/s10646-010-0582-0

Suso M. J., Gilsanz S., Duc G., Marget P. \& Moreno M. T. (2006). Germplasm management of faba bean (Vicia faba L.): Monitoring intercrossing between accessions with inter-plot barriers. Genetic Resources and Crop Evolution, 53, 14271437. https://doi.org/10.1007/s10722-005-6844-7

Taspinar M. S., Aydin M., Sigmaz B., Yagci S., Arslan E. \& Guleray Agar G. (2018). Aluminum-Induced Changes on DNA Damage, DNA Methylation and LTR Retrotransposon Polymorphism in Maize. Arab Journal of Science and
Engineering. 43:123-131. https://doi.org/10.1007/s13369017-2697-6

Thawornwong N. \& Van Diest A. (1974). Influences of high acidity and aluminum on the growth of lowland rice. Plant and Soil, 41 (1), 141-159. https://doi.org/10.1007/ BF00017951

Van't Hoff J. (1985). Control points within cell cycle. In: The cell division cycle in plants. Edited by: J.A. Bryant and Francis, D. SEB Seminar series 26. Cambridge University Press. Pp 1-13.

Yi M., Yi H., Li H. \& Wu L. (2010). Aluminum induces chromosome aberrations, micronuclei, and cell cycle dysfunction in root cells of Vicia faba. Environmental Toxicology, 25, 124-129. https://doi.org/10.1002/tox.20482

Zhang H. M., Zhang S. S., Meng Q. M., Zou J., Jiang W. S. \& Liu D. H. (2009.) Effects of aluminum on nucleoli in root tip cells, root growth and the antioxidant defense system in Vicia faba L. ACTA BIOLOGICA CRACOVIENSIA Series Botanica, 51(2), 99-10. 